\title{
Penanggulangan Orang Asing Yang Menjadi Korban Perdagangan Orang dan Penyeludupan Manusia di Bidang Keimigrasian
}

\author{
Zeleta Feba Haprifanyuna*, Mohammad Iqbal, Raditya Pandya Kusuma \\ Politeknik Imigrasi \\ *Correspondence email: zeletajpr@gmail.com, iqbalmohamad578@gmail.com, radityapk13@gmail.com
}

\begin{abstract}
Abstrak. Indonesia merupakan negara yang menarik perhatian orang asing untuk berkunjung ke Indonesia. Banyaknya peminat asing untuk mengunjungi wilayah Indonesia menjadikan imigrasi sebagai pintu gerbang Negara yang sangat pemilih dalam mengizinkan orang asing untuk masuk ke Indonesia. prosedur yang dirasa terlalu menyulitkan, munculah oknum yang dapat memudahkan orang asing masuk ke wilayah Indonesia. karena hal ini, banyak oknum yang memanfaatkan untuk meraih keuntungan dengan melakukan kejahatan berupa perdagangan orang dan penyelundupan manusia. Kajian ini menjelaskan mengenai penanganan orang asing yang menjadi korban perdagangan orang dan penyelundupan manusia selaras dengan peraturan undang-undang yang ada. Selain itu, implementasi mengenai peraturan perundang-undangan dalam hal penanganan orang asing menjadi korban perdagangan orang dan penyelundupan manusia telah dilakukan oleh pihak Keimigrasian berupa penempatan orang asing di Rumah Detensi Imigrasi atau tempat lain yangtelah ditentukan tanpa dikenai Tindakan Administratif Keimigrasian dan juga penanganan yang berbeda dengan deteni atas kasus lainnya, serta pengurusan berkas dan data dari korban perdagangan orang dan penyelundupan manusia agar dapat segera dipulangkan ke negara asalnya. Dalam melakukan pemulangan korban ke negara asal, imigrasi bekerjasama dengan kementerian luar negeri untuk mengkoordinasikan dengan perwakilan negara yang ada di Indonesia.
\end{abstract}

Kata kunci : Orang Asing; Penyeludupan Manusia; Penanganan Perdagangan Orang.

Abstract. Indonesia is a country that attracts the attention of foreigners to visit Indonesia. The number of foreign enthusiasts to visit the territory of Indonesia makes immigration a gateway for a country that is very picky in allowing foreigners to enter Indonesia. procedures that are deemed too difficult, individuals appear who can make it easier for foreigners to enter Indonesian territory. because of this, many people take advantage of it to gain profits by committing crimes in the form of human trafficking and people smuggling. This study describes the handling of foreigners who are victims of human trafficking and people smuggling in accordance with existing laws and regulations. In addition, the implementation of statutory regulations in terms of handling foreigners who become victims of trafficking in persons and people smuggling has been carried out by the Immigration Office in the form of placing foreigners in the Immigration Detention Center or other designated places without being subject to Immigration Administrative Actions and also different handling with detainees for other cases, as well as managing files and data from victims of trafficking in persons and people smuggling so that they can be immediately repatriated to their countries of origin. In repatriating victims to their countries of origin, immigration cooperates with the ministry of foreign affairs to coordinate with state representatives in Indonesia.

Keywords: Foreigners; People Smuggling; Handling Human Trafficking

\section{PENDAHULUAN}

Indonesia memanglah sebuah negara yang sangat mempesona. Selain letaknya yang strategis, Indonesia mempunyai wilayah yang terbentuk dari pulau besar dan pulau kecil dengan total sekitar 17.504 pulau. Bagian besar wilayahnya ditempati oleh laut, dengan luas +/$5.900 .000 \mathrm{~km} 2$ dan garis pantai $95.161 \mathrm{~km}$. Dengan luas tersebut, indonesia memiliki beragam suku, agama, ras, dan budaya. Keanekaragaman tersebut sangat melengkapi negara Indonesia menjadi sebuah negara yang indah dan mempesona. Karena hal tersebut, tidak mengejutkan apabila banyak orang asing ingin datang ke wilayah Indonesia untuk melakukan kegiatan seperti pariwisata, pekerjaan, hingga melakukan investasi di wilayah Indonesia.

Badan Pusat Statistik memiliki data mengenai total wisatawan mancanegara yang mengunjungi Indonesia tahun 2018, 2019, dan 2020 masing-masing berjumlah 15.806.191, 16.106.954, dan 4.022.505.
(Badan Pusat Statistik, 2021) Karena orang asing datang ke Indonesia untuk mendapatkan banyak keuntungan, bidang keimigrasian berperan penting dalam menjaga kedaulatan negara. Oleh karena itu, otoritas imigrasi mengadopsi prinsip kebijakan selektif, yang menurut kebijakan tersebut khusus orang asing yang tidak membahayakan dan ketertiban negara serta bisa memberikan manfaat untuk kesejahteraan rakyat Negara. (Alvi Syahrin, 2018) Bukan karena wisatanya saja, banyak turis mendatangi wilayah Indonesia untuk menjadi pencari suaka agar dapat ditempatkan ke negara ketiga.

Ketatnya pemerintahan Indonesia dalam memilah warga asing yang dapat memasuki wilayah Indonesia dan banyaknya keinginan warga asing untuk mengunjungi wilayah Indonesia dengan tujuan wisata maupun untuk mencari suaka, dapat memunculkan adanya oknum yang tidak bertanggung jawab memudahkan turis memasuki wilayah Indonesia. 
Akibatnya, banyak kasus mengenai turis yang secara ilegal masuk ke wilayah Indonesia. Seperti yang telah diberitakan melalui surat kabar online GoRiau.com, "telah diamankan 2 (dua) warga negara asing asal Timor Leste karena masuk indonesia secara illegal". (Farikhin, 2021) Turis asing yang secara ilegal masuk wilayah Indonesia sangat membahayakan kedaulatan wilayah Indonesia karena bisa saja orang asing tersebut memalsukan data untuk melakukan kejahatan demi keuntungan pribadi maupun kelompok. Selain adanya kasus mengenai turis asing yang secara illegal masuk ke wilayah Indonesia, kejahatan yang dapat terjadi dalam bidang keimigrasian untuk meloloskan diri masuk ke wilayah Indonesia juga terjadi pada kejahatan Perdagangan Orang (Human Trafficking) dan Penyelundupan Manuisa (People Smuggling). Sebuah berita menjelaskan mengenai adanya kegiatan penyelundupan manusia dengan beralasan menjadi pencari suaka yang dilakukan oleh puluhan imigran etnis Rohingya asal Myanmar yang kemudian ditampung di Provinsi Aceh pada Juni 2020. (Saifullah, 2020) Kabar berita tersebut hanyalah salah satu dari berbagai kasus penyelundupan manusia dan perdagangan orang yang terdapat pada wilayah Indonesia. Kejahatan penyelundupan manusia dan perdagangan orang sangat rawan terjadi di Indonesia. Rupanya tidak hanya orang yang berkewarganegaraan Indonesia saja yang dapat dieksploitasi ke Negara lain, orang asing juga bisa menjadi korban eksploitasi di wilayah Indonesia. Hal tersebut dibuktikan dengan banyaknya kasus penyelundupan manusia dan perdagangan orang asing di Indonesia. Banyaknya kejahatan ini, pemerintah Indonesia melakukan penegakkan hukum terhadap oknum yang melakukan perdagangan orang dan penyelundupan manusia serta membuat peraturan mengenai penanganan orang asing yang menjadi korban penyelundupan manusia dan perdagangan orang.

Guna memberi perlindungan terhadap korban perdagangan orang baik orang berkewarganegaraan Indonesia maupun orang berkewarganegaraan asing telah tercantum pada undang - undang yang berhubungan dengan keimigrasian telah dicantumkan pada undang - undang tentang pemberantasan tindak pidana perdagangan orang tepatnya pada Undang Undang Nomor 21 Tahun 2007 dan Peraturan Pemerintah Nomor 9 Tahun 2008 mengenai prosedur dan mekanisme pelayanan terhadap saksi dan/atau korban tindak pidana perdagangan orang. Selain pada kedua peraturan tersebut, penanganan korban perdagangan orang berkewarganegaraan asing tercantum pada Undang-Undang Nomor 6 Tahun 2011 tentang Keimigrasian. Selaras dengan pengertian dari keimigrasian yaitu suatu keadaan perlintasan orang untuk masuk maupun keluar wilayah Indonesia juga pengawasannya dengan memiliki tujuan untuk menjaga tegaknya kedaulatan negara, (Keimigrasian, 2011) Imigrasi bertanggung jawab atas pemeriksaan orang melalui perbatasan negara dari orang yang berkewarganegaraan Indonesia maupun berkewarganegaraan asing dan mengawasi kegiatan orang yang berkewarganegaraan Indonesia diluar negeri ataupun kegiatan orang berkewarganegaraan asing di wilayah Indonesia. Termasuk dalam hal penegakkan hukum terhadap orang yang telah melakukan pelanggaran keimigrasian. Sesuai dengan undang undang keimigrasian, warga asing yang melanggar peraturan keimigrasian dapat diberikan Tindakan Administratif Keimigrasian sesuai pasal 75 bahkan dapat dikenai Pidana yang telah diatur dalam pasal 113.

Dalam hal penanganan orang asing yang menjadi korban dari penyelundupan manusia serta perdagangan orang telah ditetapkan pada pasal 86 UU Keimigrasian serta diatur dalam pasal 223 pada Peraturan Pemerintah Nomor 31 Tahun 2013. Selain itu, aturan tertulis mengenai penanganan orang asing yang menjadi korban perdagangan orang tercantum dalam pasal 54 Undang Undang Nomor 21 Tahun 2007 serta tercantum pada pasal 20 Peraturan Pemerintah tentang Tata Cara dan Mekanisme Pelayanan Terpadu Bagi Saksi dan/atau Korban Tindak Pidana Perdagangan Orang. Adanya peraturan perundangan-undangan tersebut, pihak yang terlibat dalam penanganan orang asing yang menjadi korban perdaganagan orang dan penyelundupan manusia dapat mengimplementasikan perihal yang telah diatur dalam perundang-undangan yang ada. Implementasi sendiri memiliki arti pelaksanaan atau penerapan. (Nasional, 2008).

\section{METODE}

Kajian ini menggunakan metode penelitian berupa studi literatur dan studi review. Studi literatur menggunakan berbagai sumber dan bukti baik dari hasil penelitian, buku, ataupun pendapat ahli dengan tujuan untuk menyajikan konsep pengetahuan. Konsep ini ditulis dalam bentuk deskriptif-naratif dan dikutip dari berbagai sumber. (Barbara, 2020) Studi review bertujuan untuk memberikan rangkuman dari berbagai penelitian untuk digunakan sebagai latar belakang dan menyajikan gap atau celah yang perlu diisi sebagai justifikasi penelitian primer yang akan dilakukan. (Barbara, 2020).

Kajian ini menggunakan sumber data yang ada pada undang - undang, buku, jurnal dan berita yang diakses menggunakan aplikasi google. Perangkat keras yang digunakan dalam membuat kajian ini yaitu laptop dengan merek "hp" dan telepon pintar dengan merek "xiaomi". Aplikasi lainnya yang digunakan dalam penyusunan naskah jurnal ini berupa microsoft office word 2013 dan aplikasi mendeley.

\section{HASIL DAN PEMBAHASAN}

Indonesia memang memiliki daerah yang luas, namun masih mempunyai banyak celah wilayah yang selanjutnya digunakan oleh oknum yang lepas dari tanggung jawab seperti adanya penyelundupan barang 
yang terjadi di Papua dan Papua Nugini (Costa, 2021) dan penyelundupan manusia yang terjadi di Aceh. (Saifullah, 2020) Daya tarik wilayah Indonesia sangat kuat hingga orang asing di luar wilayah Indonesia sangat menginginkan datang ke Indonesia hanya untuk sekedar berwisata.

Tabel 1. Jumlah Turis Asing yang berwisata di Indonesia (Badan Pusat Statistik Provinsi Bali 2020)

\begin{tabular}{|c|c|c|}
\hline Tahun & Total & Growth $(\%)$ \\
\hline 2016 & 11.519 .275 & 10,70 \\
\hline 2017 & 14.039 .799 & 21,88 \\
\hline 2018 & 15.806 .191 & 12,58 \\
\hline 2019 & 16.106 .954 & 1,88 \\
\hline 2020 & 4.022 .505 & $-75,03$ \\
\hline
\end{tabular}

Data tersebut menjelaskan, setiap tahun sejak tahun 2016 hingga 2019, Indonesia mengalami kenaikan jumlah data mengenai turis yang datang ke Indonesia. Namun pada tahun 2020 mengalami penurunan yang signifikan karena adanya wabah corona virus. Dalam keadaan wabah corona, orang asing masih tetap melakukan wisata ke Indonesa, hal ini berarti Indonesia sangat menarik perhatian orang asing. Tabel diatas hanya membahas memberikan data mengenai wisatawan asing yang datang ke Indonesia dengan tujuan melakukan wisata, sehingga belum termasuk dalam hal orang asing berkunjung ke wilayah Indonesia untuk melakukan kegiatan penyatuan keluarga, bekerja, investasi, dan sebagainya.

Banyaknya turis asing yang masuki wilayah Indonesia membuat pemerintah Indonesia bertindak tegas dalam menghadapi orang asing yang memasuki kawasan Indonesia. Dalam hal ini imigrasi memiliki peran penting dalam menegakkan hukum yang telah ditetapkan pada perundang-undangan yang berlaku di Indonesia. Sesuai fungsi dari keimigrasian untuk melakukan pelayanan keimigrasian, menegakkan hukum, menjaga keamanan negara, dan manjadi pemfasilitasi guna membangunan kesejahteraan masyarakat dalam menjaga kedaulatan negara Indonesia Imigrasi sebagai fasilitator pembangunanan kesejahteraan masyarakat, (Undang-Undang Keimigrasian, 2011) Keimigrasian harus bisa melayanai dengan baik yang berkaitan dengan keimigrasian, menegakkan hukum yang ada di Indonesia serta pengawasannya agar dapat menjaga keamanan negara. Dengan begitu imigrasi menerapkan kebijakan berupa kebijakan selektif dimana khusus untuk orang asing yang bermanfaat bagi kesejahteraan masyarakat, bangsa, serta negara, dan juga tidak memngancam keamanan dan ketertiban. (Alvi Syahrin, 2018) Dengan adanya kebijakan tersebut orang asing dapat masuk ke kawasam Indonesia hanyalah orang asing yang bisa mengikuti prosedur untuk masuk ke kawasan Indonesia sesuai pada peraturan perundangundangan di Indonesia.

Faktanya, karena masih banyak turis asing yang yang merasa kesusahan dalam mengurus perizinan untuk masuk ke kawasan Indonesia, mereka melakukan bebagai cara agar dapat memasuki kawasan Indonesia termasuk dalam perihal yang dapat melanggar peraturan perundang-undangan ataupun kejahatan keimigrasian. Beberapa waktu terakhir di wilayah Indonesia telah menangkap imigran yang tidak sah dari daerah Timur Tengah karena telah melakukan perjalanan menggunakan dokumen dan visa palsu atau tidak memiliki dokumen yang resmi.(Yulistini and Arabiyah, 2017) Dibalik terjadinya pelanggaran dan kejahatan keimigrasian turis asing yang masuk ke kawasan Indonesia dengan cara tidak resmi terdapat oknum yang siap membantu turis asing tersebut untuk dapat masuk ke kawasan Indonesia dengan melakukan pemalsukan dokumen penting seperti paspor, memalsukan tanda masuk, dan sebagainya. Keadaan Indonesia yang sangat luas dan banyak daerah-daerah pedalaman yang belum terjangkau oleh imigrasi tidak hanya berpotensi adanya pelanggaran keimigrasian, bahkan bisa saja terjadi kejahatan keimigrasian. Daerah pedalaman yang belum terjangkau oleh imigrasi dapat dijadikan celah dalam melakukan kejahatan keimigrasian berupa penyelundupan manusia maupun perdagangan orang. Berita - berita yang memberikan informasi mengenai penyelundupan manusia dan perdagangan orang yang ada di Indonesia biasanya terjadi pada jalur-jalur kecil yang tidak terjangkau imigrasi atau dapat dikatakan sebagai jalur tikus. Meskipun tidak semuanya melalui jalur tersebut.

Dalam hal kejahatan keimigrasian, indonesia memiliki permasalahan berupa penyelundupan manusia dan perdagangan orang. Pengertian dari penyelundupan manusia yaitu sesuatu yang memiliki tujuan untuk mendapatkan keuntungan secara langsung ataupun secara tidak, untuk kepentingan diri sendiri ataupun orang lain yang membawa seorang atau gabungan orang secara terencana maupun tidak, atau dengan memerintah orang lain untuk membawa seorang atau gabungan orang secara terstruktur maupun tidak terstruktur, yang tidak mempunyai hak yang resmi untuk masuk ataupun keluar kawasan Indonesia dan / atau masuk kawasan negara lain yang orang itu tidak punya hak masuk ke kawasan tersebut secara resmi dengan menggunakan dokumen yang sah dan masih belaku maupun dokumen palsu, atau bahkan tanpa menggunakan dokumen perjalanan, baik melewati pemeriksaan imigrasi maupun tidak. (Keimigrasian, 2011) Sedangkan perdagangan orang yaitu suatu perbuatan berupa merekrut, mengangkut, menampung, mengiriman, memindah, ataupun menerima seseorang dengan diberikan peringatan dan perlakuan dengan menggunakan kekerasan, menculik, menyekap, memalsukan, menipu, bahkan menyalahgunakan kekuasaan atau posisi lemah, dengan menjerat hutang ataupun membayar atau memanfaatkan, sehingga bisa mendapatkan persetujuan dari seseorang yang menjadi kepala atas orang lain itu yang dilakukannya di dalam maupun antar negara, dengan tujuan eksploitasi atau bahkan mengakibatkan orang 
tereksploitasi. (Indonesia 2007) Dari pengertian tersebut, banyak orang yang memanfaatkan keadaan untuk menjadi oknum agar mempermudah orang asing masuk ke Wilayah Indonesia.

Di era saat ini, kasus perdagangan terhadap orang merupakan karakter lain dari perilaku memperbudak manusia. selain itu, perdagangan manusia juga salah satu wujud tindakan buruk dari pengebirian manusia dalam harkat dan martabatnya (Kamal, 2019) dengan memiliki tujuan untuk melakukan kerja paksa dengan menempatkan ataupun menahan pekerja itu dengan dibayar maupun tidak, untuk melakukan pekerjaan yang tidak sesuai dengan keinginannya (domestik, seksual atau reproduktif), ikatan kerja atau seperti perbudakan di suatu wilayah lain disuatu tempat dimana pekerja tersebut tinggal pada saat penipuan, tekanan, ataupun lilitan utang pertama kali. (Susiana et al, 2015) Selain perdagangan orang, Penyelundupan manusia menjadi masalah yang perlunditangani dengan serius. Penyelundupan manusia adalah suatu bentuk kejahatan lintas negara yang terstruktur dan terencana yang memiliki potensi untuk menciptakan berbagai kejahatan lain. (Julianthy, 2020) pendapat lain mengatakan, penyelundupan merupakan kejahatan terorganisr yang melibatkan banyak orang dan jaringan yang luas. (Missbach and Purdey, 2017) Dalam hal ini, korban eksploitasi manusia di luar negeri bukan hanya berasal dari orang yang berkewarganegaraan Indonesia saja, Namun ternyata Indonesia memiliki banyak korban asing yang dari tindak penyelundupan manusia dan perdagangan orang di kawasan Indonesia.

Seperti kasus yang melibatkan warga negara Bangladesh dimana telah ditemukan tengah kelaparan disebuah rumah toko atau ruko di daerah Medan, Sumatera Utara. (Andriansyah, 2019) Sebanyak 193 orang asing yang menjadi korban perdagangan orang tersebut telah diamankan oleh petugas Imigrasi karena tidak memiliki dokumen keimigrasian dan ditempatkan di Rumah Detensi Imigrasi Belawan. Setelah melakukan pemeriksaan, petugas Imigrasi mendapatkan hasil bahwa 193 orang asing yang menjadi korban tersebut sudah berada di wilayah Indonesia lebih dari 1 bulan, dan ditemukannya 14 buku paspor. (Andriansyah, 2019) Setelah mendapatkan berkas-berkas yang dibutuhkan, pejabat imigrasi segera mengurus orang asing korban perdagangan orang tersebut untuk kembali ke negara asalnya.

Karena adanya permasalahan tersebut, imigrasi mengatur semua hal yang berhubungan denegan keimigrasian pada Undang-Undang Nomor 6 Tahun 2011 tentang Keimigrasian yang selanjutnya disebut dengan undang - undang keimigrasian. Didalam undang undang ini, telah dijelaskan hukuman yang akan didapatkan oleh orang asing maupun orang berkewarganegaraan Indonesia yang telah melanggar peraturan keimigrasian. Sesuai dengan undang - undang keimigrasian, pengertian dari Keimigrasian yaitu suatu peristiwa perlintasan orang yang keluar ataupun masuk ke kawasan Indonesia dengan melakukan pengawasan dengan tujuan untuk menjaga kedaulatan negara Indonesia (Keimigrasian, 2011) Imigrasi bertanggung jawab atas orang yang melalui perbatasan negara dari orang yang berkewarganegaraan Indonesia maupun berkewarganegaraan asing serta melakukan pengawasan terhadap kegiatan orang yang berkewarganegaraan Indonesia diluar negeri serta kegiatan orang berkewarganegaraan asing yang berada di Indonesia. Termasuk dalam hal penegakkan hukum terhadap orang yang telah melakukan pelanggaran keimigrasian. Sesuai dengan undang - undang keimigrasian, orang asing di Indonesia yang melanggar peraturan keimigrasian dapat dikenai Tindakan Administratif Keimigrasian yang telah diatur dalam pasal 75 dan dapat dikenai Pidana yang telah diatur dalam pasal 113. Dalam hal penanganan orang asing yang menjadi korban penyelundupan manusia dan perdagangan orang juga telah diatur pada Undang-Undang yang sama pada Pasal 86 serta diatur dalam pasal 223 pada Peraturan Pemerintah Nomor 31 Tahun 2013.

Undang - undang tentang keimigrasian tidak hanya mengatur keimigrasian secara umum dan hukuman yang diberikan kepada pelaku kejahatan keimigrasian yang berupa Tindakan Administratif Keimigrasian dan Pidana, namun juga mengatur tentang penanganan dari korban kejahatan keimigrasian penyelundupan manusia dan perdagangan orang. Penanganan terhadap korban perdagangan orang dan penyelundupan.manusia sudah diatur dalam Bab VIII Undang - Undang Nomor 6 Tahun 2011.

1. Pasal.86 menyatakan bahwa korban dari perdagangan orang dan juga penyelundupan manusia tidak dapat diberlakukannya tindak administratif keimigrasian.

2. Pasal.87 menyatakan bahwa korban dari tindakan perdagangan orang dan penyelundupan manusia yang berada di kawasan Indonesia akan ditempatkan pada Rumah Detensi Imigrasi atupun tempat lainnya yang sudah ditetapkan dengan mendapatkan perlakuan khusus daripada orang asing penghuni Rumah Detensi Imigrasi karena melakukan pelanggaran keimigrasian. Dalam undang - undang keimigrasian pasal.87 menyebutkan kalimat "deteni pada umumnya" yang dimaksudkan kepada deteni yang melakukan pelanggaran keimigrasian karena overstay, penyalahgunaan visa, dan sebagainya.

3. Pasal.88 menyatakan bahwa korban asing dari tindakan perdagangan orang dan juga penyelundupan manusia untuk dikembalikan ke negara asalnya yang di upayakan oleh menteri ataupun pejabat imigrasi yang telah diberikan perintah.

4. Pasal.90 menyatakan bahwa akan diciptakannya peraturan pemerintah apabila terdapat ketentuan lebih lanjut mengenai adanya rumah detensi imigrasi, pengawasa dan intelijen keimigrasian, dan 
penanganan untuk korban dari tindakan perdaganan.orang dan penyelundupan.manusia.

Dari Pembahasan diatas, dapat disimpulkan bahwa dalam menangni orang asing yang menjadi mangsa dari tindakan perdagangan.orang dan penyelundupan manusia akan diberikan tempat di Rumah detensi ataupun bangunan lain yang telah diputuskan dengan menerima pelayanan yang berbeda dari deteni yang melakukan pelanggaran keimigrasian lainnya. Orang asing yang menjadi mangsa dari tindak perdagangan orang dan penyelundupan manusia tidak akan diberikan hukuman administratif keimigrasian dan segera diupayakan oleh pemerintah Indonesia untuk pulangkan ke negara asal serta akan diberikan dokumen perjalanan berbbentuk surat apabila korban tersebut tidak memiliki. Apabila ada ketentuan lainnya akan dituangkan pada Peraturan Pemerintah.

Selain dari undang-undang keimigrasian, peraturan yang mengatur mengenai penanganan untuk orang asing yang menjadi mangsa dari tindakan perdagangan.orang dan penyelundupan.manusia terdapat pada pasal 54 ayat (2) dan (3) Undang - Undang. Nomor 21 Tahun 2007 tentang Pemberantasan Tindak.Pidana.Perdagangan Orang. maksud dari pasal 54 ayat (2) dan (3) yaitu koban penyelundupan manusia dan perdagangan orang adalah orang berkewarganegaraan asing, pemerintah akan melindungi dan mengupayakan pemulangan ke negara asal dari korban tersebut dengan melakukan koordinasi bersama perwakilan negaranya di Indonesia dengan tetap memperhatikan ketentuan peraturan perundang - undang dan hukum ataupun kebiasaan internasional. Peraturan lainnya yang mengatur tentang orang asing yang menjadi korban perdagangan orang dan penyelundupan tercantum dalam Peraturan Pemerintah Republik Indonesia Nomor 9 Tahun.2008 tentang Tata.Cara.dan Mekanisme Pelayanan Terpadu Bagi Saksi dan/atau Korban Tindak Pidana Perdagangan Orang. Menurut pasal 20 dalam Peraturan.Pemerintah.Nomor 9 Tahun 2008 menyatakan bahwa Menteri luar negeri Indonesia wajib berkoordinasi dengan istansi yang terkait dan juga dengan perwakilan negara saksi dan/atau korban ataupun perwakilan negara yang telah diakreditasikan apabila negara asal dari saksi dan/atau korban tidak memiliki perwakilan negara yang ada di Indonesia apabila saksi dan/atau korban teridentifikasi berkewarganegaraan asing Dengan peraturan yang ada di Indonesia mengenai orang asing yang menjadi korban penyelundupan manusia dan perdagangan orang, pemerintah Indonesia melakukan implementasi sesuai dengan yang telah ditetapkan dalam peraturan perundang - undangan yang ada. Peraturan pemerintah disini yaitu pemerintah dalam bidang keimirasian dan kementerian luar negeri. Pada kenyataan lapangan, peraturan tersebut telah dikerjakan oleh pemerintah indonesia yang terkait. Ketika orang asing melaporkan diri ataupun adanya pengaduan masyarakat secara eksklusif ataupun pengaduan secara online dengan menggunakan Aplikasi Pelaporan Orang Asing (APOA), pihak imigrasi mengamankan dan menempatkan orang asing tersebut ke suat tempat khusus untuk pendetensian yang dimiliki oleh imigrasi maupun tempat lain yang telah disediakan dengan penanganan deteni yang berbeda dengan deteni yang melakukan pelanggaran keimigrasian seperti overstay, penyalah gunaan visa, dan sebagainya Orang asing yang menghuni Rumah Detensi Imigrasi atau Ruang Detensi Imigrasi yang sudah memiliki keputusan dari pejabat imigrasi untuk dilakukannya pendetensian disebut deteni. (Keimigrasian, 2011) Ketika orang asing yang menjadi korban ditempatkan di Rumah Detensi Imigrasi, pihak keimigrasian segera melakukan prosedur pengembalian orang asing ke negara asalnya. Pada fakta lapangan, keimigrasian telah melaksanakan sebagaima yang diatur di dalam peraturan. Pada tahun 2019 lalu, penemuan warga negara Bangladesh sebanyak 193 orang di Medan yang diduga sebagai perdagangan orang itu di tempatkan di Rumah Detensi Imigrasi. (Muhardiansyah, 2019) Setelahnya, pihak imigrasi akan mengurus semua berkas-berkas yang ada termasuk pembuatan surat perjalanan apabila korban tidak memilikya untuk melakukan tindakan paksa melakukan pengeluaran orang asing dari kawasan Indonesia. (Keimigrasian, 2011) Setelah berkas siap, keimigrasian berkerjasama dengan kementerian luar negeri dengan perwakilan negara korban.perdagangan.orang dan penyelundupan.manusia. Apabila negara korban tidak ada perwakilannya di Indonesia, maka menteri luar negeri dapat melaporkan ke perwakilan negara asing yang telah diakreditasikan untuk wilayah Indonesia agar dapat melakukan pemulangan korban.perdagangan orang dan penyelundupan manusia (Peraturan Pemerintah Nomor 9 Tahun 2008) dengan tidak melupakan ketentuan peraturan perundang-undangan dan hukum ataupun kebiasaan internasional yang ada. (Undang-Undang Nomor 21 Tahun 2007)

Karena permasalahan yang ada, pemerintahan Indonesia juga mununjukan komitmen yang serius dalam penanggulangan tindak perdagangan dan penyelundupan orang. Komitmen ini dibuktikan dengan kordinasi melalui hubungan baik pemerintahan negara. Dalam perihal ini, badan koordinasi utama adalah Kantor Kementrian Koordinasi Politik, Hukum dan Keamanan. Melalui desk penyelundupan manusia-badan nasional antar departemen untuk pengungsi, pencari suaka, dan penyelundupan manusia terjalin kerjasama dengan Kepolisian Republik Indonesia, kementrian luar negeri dan imigrasi yang kemudian dibentuklah Penanganan Penyelundupan Manusia, Pengungsi dan Pencari Suaka (P2MP2S). 


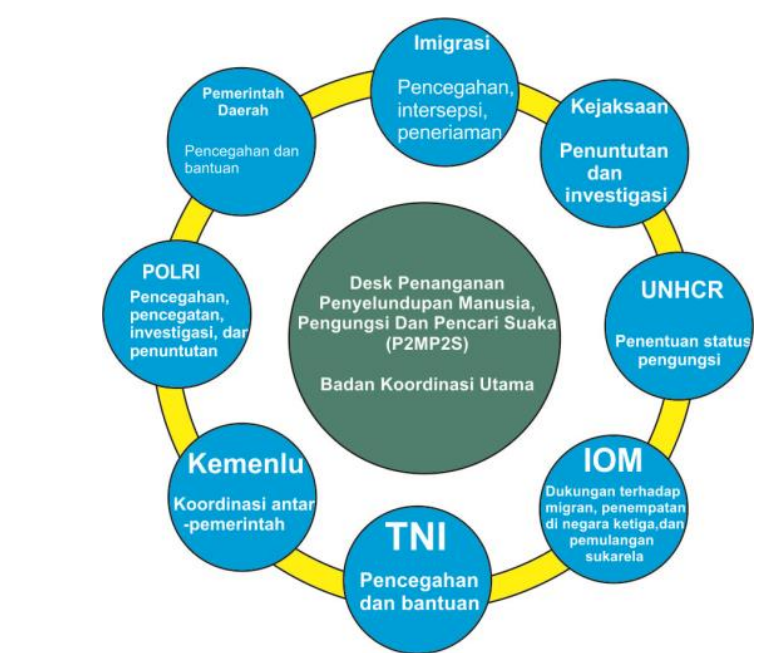

Gambar 1. Desk Penanganan Penyelundupan Manusia, Pengungsi, dan Pencari Suaka

Penyelundupan Manusia, Pengungsi dan Pencari Suaka (P2MP2S) merupakan badan koordinasi utama, dimana P2MP2S melakukan koordinasi dengan beberapa lembaga pemerintahan seperti, P2MP2S melakukan koordinasi dengan Imigrasi dalam pencegahan, interpesepsi dan penerimaan kasus perdagangan manusia di Indonesia, P2MP2S berkoordinasi dengan Kejaksaan dalam melakukan penuntutan dan investigasi kasus perdagangan manusia di Indonesia, P2MP2S berkoordinasi dengan IOM dalam memberi dukungan terhadap migran, serta dalam memberikan penempatan di tempat ketiga dan pemulangan kembali ke dengan sukarela, P2MP2S berkoordinasi dengan UNHCR dalam penentuan status perdagangan manusia dari luar ke Indonesia, P2MP2S berkoordinasi dengan TNI dalam pencegahan perdagangan manusia serta memberikan bantuan bagi para korban, P2MP2S berkoordinasi dengan pemerintah daerah dalam pencegahanpencegahan untuk tidak terjadinya kasus-kasus pedagangan manusia di berbagai daerah di Indonesia serta memberikan bantuan kepada para korban di daerahdaerah yang sudah terjerat kasus perdagangan manusia, P2MP2S berkoordinasi dengan kemenlu untuk lalu dikoordinasikan kembali antar pemerintah, P2MP2S berkoordinasi dengan POLRI dalam pencegahan, pencegatan, investigasi dan penuntutn terhadap kasus perdagangan manusia di Indonesia, serta P2MP2S berkoordinasi dengan imigrasi dalam pencegahan, intersepsi dan penerimaan kasus perdagangan manusia di Indonesia. (Oktavian and Alif, 2018)

Selain pembuatan P2MP2S, Pemerintah juga mencantumkan upaya yang perlu dilakukan dalam mencegah terjadinya perdagangan.orang ataupun.penyelundupan manusia. Upaya tersebut berupa upaya preventif dan upaya represif dengan penjelasannya (Undang - Undang Keimigrasian, 2011) yaitu :

\section{Upaya Preventif}

a. pertukaran informasi dengan negara lain dan instansi terkait di dalam negeri, meliputi modus operandi, pengawasan dan pengamanan Dokumen Perjalanan, serta legitimasi dan validitas dokumen;

b. kerja sama teknis dan pelatihan dengan negara lain meliputi perlakuan yang berdasarkan perikemanusiaan terhadap korban, pengamanan dan kualitas Dokumen Perjalanan, deteksi dokumen palsu, pertukaran informasi, serta pemantauan dan deteksi Penyelundupan Manusia dengan cara konvensional dan nonkonvensional;

c. memberikan penyuluhan hukum kepada masyarakat bahwa perbuatan perdagangan orang dan Penyelundupan Manusia merupakan tindak pidana agar orang tidak menjadi korban;

d. menjamin bahwa Dokumen Perjalanan atau identitas yang dikeluarkan berkualitas sehingga dokumen tersebut tidak mudah disalahgunakan, dipalsukan, diubah, ditiru, atau diterbitkan secara melawan hukum; dan

e. memastikan bahwa integritas dan pengamanan Dokumen Perjalanan yang dikeluarkan atau diterbitkan oleh atau atas nama negara untuk mencegah pembuatan dokumen tersebut secara melawan hukum dalam hal penerbitan dan penggunaannya

2. Upaya Represif

a. penyidikan Keimigrasian terhadap pelaku tindak pidana perdagangan orang dan Penyelundupan Manusia;

b. Tindakan Administratif Keimigrasian terhadap pelaku tindak pidana perdagangan orang dan Penyelundupan Manusia; dan

c. kerja sama dalam bidang penyidikan dengan instansi penegak hukum lainnya.

Dalam penyidikan, imigrasi dibantu oleh instansi yang terkait yaitu polri. Asas legalitas dalam pelaksanaan paradigma hokum dinyatakan dalam undang-undang nomor 2 tahun 2002 tentang kepolisian. Dalam pasal 14 dalam undang-undang ini, termuat perincian tugas dan wewenang kepolisian negara republic Indonesia, yaitu melakukan penyelidikan dan penyidikan terhadap semua tindak pidana sesuai dengan hokum acara pidana dan peraturan perundang-undangan lainnya.

Pada ayat 1 huruf g, berbunyi: "melakukan penyelidikan dan penyidikan terhadap semua tindak pidana sesuai dengan hukum acara pidana dan peraturan perundang-undangan lainnya".

Hal ini sesuai dengan jurnal keimigrasian yang berjudul "Kasus Pengungkapan Jaringan Penyelundupan Manusia Oleh Polri Di Dumai Dalam Lensa Penindakan Keimigrasian" yang ditulis oleh Fachrizza Sidi Pratama, bahwa dalam tulisannya, kasus tindak pidana 
keimigrasian ditemukan dan ditangani oleh penyidik kepolisian dan dengan menggunakan undang-undang keimigrasian.

Dalam tulisan ini, kepolisian menemukan sindikat penyelundupan orang dimulai dengan penemuan orang asing yang diketahui berwarganegara Bangladesh mencurigakan ketika patroli di kawasan Sidomulyo, Dumai pada tanggal 19 Februari 2017. Kemudian penemuan tersebut membawa penemuan sebanyak 74 WNA yang diantaranya terdapat 31 orang telah habis berlaku visa dan paspor yang kadaluarsa. Ditemukan fakta bahwa wna tersebut akan diselundupkan ke negara autralia dan Malaysia. Dalam kasus ini, didapati kerjasama antara bareskrim, Interpol, dan kepolisian Perancis. Namun fahrizza menyebutkan tidak adanya peran ppns keimigrasian dalam penanganan kasus tersebut. Tidak adanya intervensi ppns keimigrasian tersebut karena beberapa hambatan yang dialami. Antara lain:

1. PPNS keimigrasian merupakan pekerjaan yang dilekatkan dengan tugas bidang keimigrasian yang ada sehingga tugas penyidikan masih belum dilaksanakan dengan baik. PPNS keimigrasian tidak hanya dibebani dengan tugas penyelidikan namun dibebani dengan tugas administrasi sehingga tugas penyidikan ditentukan dengan skala prioritas dari pekerjaan yang ada.

2. Terbatasnya sumber daya manusia yang ada (personel), sehingga penanganna tindakan pidana keimigrasian berjalan kurang cepat

3. Kualitas sumber daya belum memadai karena kurangnya pelatihan penyidikan dalam imigrasi dan juga belum adanya kurikulum pengajaran tentang penyidikan

Selain upaya preventif dan represif yang dilakukan oleh keimigrasian, polri dan instansi terkait lainnya, pemerintahan Indonesia juga mununjukan komitmen yang serius dalam penanggulangan tindak perdagangan dan penyelundupan orang. Komitmen ini dibuktikan dengan adanya kerjasama Indonesia pada tahun 2001 dengan Australia dan IOM yang bertujuan untuk membantu para migran gelap untuk pulang secara sukarela atau menempatkan mereka di negara ketiga, dan guna mencegah Indonesia dan Australia menjadi negara sasaran bagi pelaku perdangangan dan penyelundupan manusia. Dalam kesepakatan ini, Australia memberikan dana sebesar kepada IOM Indonesia sebesar US\$ 50.000.000 untuk digunakan untuk pembiayaan layananlayanan yang diberikan kepada para korban selama mereka berada di Indonesia serta untuk mendukung upaya Pemerintah Indonesia dalam manajemen penanganan perdagangan orang, penyelundupan manusia, dan alur migrasi gelap melalui wilayahnya. (Putri, 2021)

IOM (International Organization for Migration) merupakan organisasi internasional dan juga antar pemerintah Indonesia yang didirikan pada tahun 1995 sebagau organisasi terdepan dan berdedikasi untuk mempromosikan migrasi yang berperikemanusiaan dan teratur serta bermanfaat bagi semua. (Migration and Indonesia n.d.) Dalam kasus Perdagangan dan Perbudakan Manusia di Industri Perikanan PT. Pusaka Benjina Resource Tahun 2015 yang ditulis oleh Diah Ajeng Ariestya Putri, Sebagai bagian dari Program Bantuan bagi Korban, IOM Indonesia bekerja sama dengan pemerintah Indonesia termasuk Kementerian Kelautan dan Perikanan untuk memberikan bantuan kesehatan, pangan, non-pangan seperti pakaian layak, kerjasama dengan Kedutaan Besar di Indonesia untuk memulangkan para korban ke negara asal mereka dengan koordinasi dengan Kedutaan di negara-negara asal dan IOM di berbagai negara guna mengumpulkan informasi korban yang selanjutnya berkoordinasi dengan Direktorat Jendral Imigrasi Indonesia yang kemudian Kantor imigrasi memberikan dokumen imigrasi untuk meninggalkan indonesia, serta berkoordinasi dengan Kementerian Sosial, berbagai pemerintahan daerah untuk memberikan penampungan serta perlindungan sementara kepada para korban sebelum dipulangkan atau diberikan izin tinggal menetap.

IOM juga memberikan bantuan reintegrasi kepada korban dengan memberikan bantuan penghidupan kepada korban dari IOM negara asal korban dan berkoordinasi dengan Kantor Imigrasi, Polri dan Kementerian Tenaga Kerja untuk proses pelunansan gaji. Selain itu, IOM menyerahkan proses hokum oleh kejaksaan kepada Kejaksaan yang kemudian Polri bekerjasama dengan Lembaga Perlindungan Saksi dan Korban (LPSK) serta kejaksaan agung untuk menuntut tersangka di peradilan Indonesia.

\section{SIMPULAN}

Penanganan orang asing yang menjadi korban perdagangan orang berdasarkan Undang - Undang Nomor 6 Tahun 2011 tentang.Keimigrasian berupa :

1. Korban dengan kewarganegaraan asing dari tindak pidana.perdagangan,orang dan penyelundupan manusia akan diberikan tempat pada Rumah, Detensi, Imigrasi, ataupun disuatu tempat yang sudah ditentukan sebelumnya;

2. Selama berada di rumah detensi imigrasi ataupun disuatu tempat lainnya yang telah ditentukan orang asing yang menjadi korban tindak pidana perdagangan orang serta, penyelundupan manusia akan diperlakukan secara nerneda daripada deteni yang melakukan suatu pelanggaran keimigrasian.

3. Orang asing yang menjadi korban dari suatu tindak.perdagangan,orang dan penyelundupan.manusia tidak dikenakan hukuman administratif keimigrasian;

4. Pengupayaan kepulangan orang asing yang menjadi korban dari perdagangan orang dan juga penyelundupan manusia oleh pemerintah Indonesia 
pada bidang keimigrasian yang diwakilkan oleh pejabat imigrasi yang telah diberikan tugas ataupun menteri. Termasuk dalam urusan pembuatan surat perjalanan apabila orang asing tersebut tidak mempunyainya.

Penanganan orang asing yang menjadi korban,.perdagangan,orang dan,penyelundupan manusia yang didalam Undang - Undang tentang Pemberantasan Tindak Pidana Perdagangan Orang, berupa :

1. Pemerintah Indonesia mengupayakan perlindungan dan pemulangan ke negara asal dari orang asing yang menjadi korban perdaganagan, orang,dan, penyelundupan manusia,yang bertempat di Indonesia dengan cara koordinasi dengan perwakilan negaranya di Indonesia.

2. Pemberian perlindungan untuk orang asing yang menjadi.korban,perdagangan orang dan penyelundupan manusia dengan tetap memperhatikan ketentuan dari peraturan perundang-undangan serta hukum ataupun kebiasaan internasional.

Penanganan orang asing yang menjadi korban dari suatu tindakan perdagangan manusia dan penyelundupan,.manusia pada Peraturan Pemerintah Nomor 9 Tahun 2008 mengenai prosedur pelayanan terstruktur untuyk saksi dan/atau korban dari tindakan perdagangan,orang, berupa :

1. Untuk membantu kepulangan korban asing dari tindakan perdagangan,orang, menteri luar negeri Indonesia harus melakukan koordinasi bersama dengan institusi yang terkait dan perwakilan negara asal dari korban asing itu.

2. Dalam pemulangan korban asing dari tinda pidana perdaganganoorang dannpenyelundupan manusia, semua biaya yang diperlukan dibebankan kepadaperwakilan negara dari korban itu yang ada di Indonesia dan harus dilakukan sesuai dengan peraturan yang ada.

3. Apabila orang asing yang menjadi korban perdaganganoorang danppenyelundupanomanusia negaranya tidak memilikioperwakilan negara di Indonesia, menteri luar negeri menginformasikan kepada perwakilan negara asing yang telah terakreditasi untuk negara tersebut di Wilayah Indonesia.

Dengan melakukan penanganan yang ada pada peraturan perundang-undangan, pengimplementasian pemerintah Indonesia dalam hal penanganan orang asing yang menjadi korban,perdagangan,orang,dan penyelundupan manusia yaitu :

1. Penanganan dimulai dari ditemukannya orang asing yang menjadi korban dari tindakan perdaganganoorang dannpenyelundupanmmanusia. Masyarakat dan pihak berwajib terutama pihak imigrasi memiliki peran dalam hal ini. Dalam hal ini imigrasi memiliki APOA yang merupakan singkatan dari Aplikasi Pelaporan Orang Asing untuk melaporkan aktivitas orang asinggyang ada disekitar masyarakat.

2. Orang asing yang menjadi korban keimigrasian diberikan tempat suatu tempat untuk pendetensian milik imigrasi yang biasanya disebut rumah detensi imigrasi ataupun dilain tempat yang telah diberikan ketentuan. Imigrasi menjadi peran utama dalam hal ini.

3. Selama di tempat khusus pendetensian yang disebut rumah detensi imigrasi ataupun dilain tempat yang sudah ditentukan, orang asing yang menjadi korban dari tindakanpperdagangan orang,dan penyelundupan,manusia tidak akan diberikan hukuman administratif keimigrasian bahkan diberikan perlakuan khusus daripada orang asing yang berada di tempat khusus pendetensian milik imigrasi ataupun tempat lain yang sudah ditentukan karena melakukan pelanggaran dan dalam hal ini imigrasi memiliki peran penting.

4. Pemerintah Indonesia dalam hal ini adalah Imigrasi dan kementerian luar negeri melakukan koordinasi dengan perwakilan negara dari korban asing dari suatu tindakan,perdagangan,orang dan penyelundupanmmanusia yanggberada di Indonesia untuk melakukan pemulangan ke negara asal. Apabila negara korban asing itu tidak ada perwakilan negara di Indonesia, menteri luar negeri Indonesia memberikan informasi kepada negara korban asing tersebut pada perwakilan negara yang terakreditasi dan terdekat dengannwilayah Indonesia.

5. Perlindungan dan pemulanhan orang asing yang menjadi korban perdagangan orang dan penyelundupan manusia dilakukan sesuai dengan ketentuan peraturan perundang-undangan, hukum internasional, atau kebiasaan internasional yang ada.

Dalam rangka pencegahan terjadinya tindak pidana perdagangan orang dan penyelundupan manusia, Menteri ataupun Pejabat Imigrasi yang ditunjuk melakukan upaya preventiffdan represif sesua dengan undang - undang keimigrasian. Upaya yang canangkan yaitu berupa :

\section{Upaya Preventif}

a. Bekerjasama dengan institusi lain ataupun negara lain untuk melakukan barter informasi yang terkait dengan pengawasan dan pengamanan dokumen perjalanan, modus operandi, dan juga legitimasi dan validasi dokumen;

b. Melakukan kerja sama secara teknis serta adanya pelatihan dengan negara lain dalam hal perlakuan yang berdasarkan perikemanusiaan terhadap korban, pengamanan dan kualitas Dokumen Perjalanan, deteksi dokumen palsu, pertukaran informasi, serta pemantauan dan deteksi 
Penyelundupan Manusia dengan cara konvensional dan nonkonvensional;

c. Memberikan penyuluhan tentang hukum kepada masyarakat bahwa perbuatan perdagangan orang dan penyelundupan manusia merupakan tindak pidana;

d. Memberikan jaminan bahwa dokumen perjalanan atau identitas yang dikeluarkan memiliki kualitas sehingga dokumen itu tidak mudah disalahgunakan dipalsukan, diubah, ditiru, ataupun diterbitkan secara melawan hukum; dan

e. Memberikan kepastian bahwa integritas dan pengamanan dokumen perjalanan yang dikeluarkan,atau diterbitkan oleh atau atas nama negara untuk mencegah pembuatan dokumen tersebut secara melawan hukum dalam hal penerbitan dan penggunaannya

2. Upaya Represif

a. Dilakukannya penyidikan keimigrasian terhadap pelaku tindak pidana perdagangan orang dan penyelundupan manusia;

b. Diberikannya tindakan administratif keimigrasian terhadap pelaku tindak pidana perdagangan orang dan penyelundupan manusia; dan

c. Diadakannya kerja sama dalam bidang penyidikan dengan institusi penegak hukum lainnya.

Dengan adanya upaya dari pemerintahan Indonesia, diharapkan tindak pidana perdagangan orang dan penyelundupan manusia yang menjadikan orang asing korban di wilayah Indonesia dapat berkurang bahkan tidak ditemui lagi kasus seperti itu.

\section{DAFTAR PUSTAKA}

Alvi Syahrin, Muhammad. 2018. "Teori Kebijakan Selektif Keimigrasian." Petak Norma. Retrieved March 26, 2021 (http://www.petaknorma.com/2018/09/teorikebijakan-selektif-keimigrasian.html).

Andriansyah, Anugrah. 2019. "Ditemukan Dalam Kondisi Kelaparan, Ratusan WNA Asal Bangladesh Diamankan." Voaindonesia.Com. Retrieved March 27, 2021 (https://www.voaindonesia.com/a/ditemukandalam-kondisi-kelaparan-ratusan-wna-asalbangladesh-diamankan/4774782.html).

Anon. 2008. Peraturan Pemerintah Nomor 9 Tahun 2008 Tentang Tata Cara Dan Mekanisme Pelayanan Terpadu Bagi Saksi Dan/Atau Korban Tindak Pidana Perdagangan Orang. Indonesia.

Badan Pusat Statistik. 2021. "Jumlah Wisatawan Ke Indonesia Dan Bali, 1969-2020." Badan Pusat Statistik. Retrieved March 25, 2021 (https://bali.bps.go.id/statictable/2018/02/09/28/ba nyaknya-wisatawan-mancanegara-ke-bali-danindonesia-1969-2020.html).

Badan Pusat Statistik Provinsi Bali. 2020. "Jumlah
Wisatawan Asing Ke Indonesia Dan Bali, 19692020." Badan Pusat Statistik Provinsi Bali. Retrieved March 28, 2021 (https://bali.bps.go.id/statictable/2018/02/09/28/ju mlah-wisatawan-asing-ke-bali-dan-indonesia1969-2019.html).

Barbara, Laksita. 2020. SYISTEMATIC REVIEW DALAM KESEHATAN: LANGKAH DEMI LANGKAH. Yogyakarta: Penerbit Deeppublish.

Costa, Fabio Maria Lopes. 2021. "Imigrasi Ungkap Tujuh Jalur Transaksi Ilegal Di Perbatasan RIPNG." Kompas, March 26.

Farikhin. 2021. "Imigrasi Tembilahan Amankan Imigran Gelap Asal Timor Leste, Masuk Indonesia Lewat Jalur Tikus." GoRiau.Com, March 26.

Indonesia. 2007. Undang-Undang Nomor 21 Tahun 2007 Tentang Pemberantasan Tindak Pidana Perdagangan Orang. Indonesia.

Indonesia. 2011. Undang-Undang Nomor 6 Tahun 2011 Tentang Keimigrasian. Indonesia.

Julianthy, Evlyn Martha. 2020. Kebijakan Kriminal Terhadap Penyelundupan Manusia. Medan: Enam Mefia.

Kamal, Muhammad. 2019. Human Trafficking. Makassar: CV. Social Politic Genius (SIGn).

Migration, International Organization for, and Mission in Indonesia. n.d. "International Organization for Migration Indonesia." IOM UN MIGRATION. Retrieved (https://indonesia.iom.int/id/internationalorganization-migration-indonesia).

Missbach, Antje, and Jemma Purdey. 2017. Linking People: Pertalian Dan Interaksi Orang Australia Dan Orang Indonesia. Jakarta: PT. Gramedia.

Muhardiansyah, Yan. 2019. "Diduga Korban Perdagangan Manusia, 193 WN Bangladesh Disekap Dalam Ruko Di Medan.” Merdeka.Com. Retrieved March 27, 2021 (https://www.merdeka.com/peristiwa/didugakorban-perdagangan-manusia-193-wnbangladesh-disekap-dalam-ruko-di-medan.html).

Nasional, Departemen Pendidikan. 2008. Kamus Besar Bahasa Indonesia. Jakarta: Pusat Bahasa Departemen Pendidikan Nasional.

Oktavian, and Alif. 2018. "Peran International Organization of Migration (IOM) Dalam Menanggulangi Kasus Human Trafficking Di Indonesia." Prosiding Senaspolhi 1(1).

Putri, Gloria Setyvani. 2021. "Waspada Kemungkinan Munculnya Varian Baru Corona Asal Indonesia." Kompas.Com. Retrieved August 10, 2021 (https://www.kompas.com/sains/read/2021/07/19/ 080200923/waspada-kemungkinan-munculnyavarian-baru-corona-asal-indonesia?page=all).

Saifullah, Muhammad. 2020. "Warga Rohingya Yang Terdampar Di Aceh Ternyata Korban Penyelundupan." IDN Times. Retrieved March 26, 
Zeleta Feba Haprifanyuna, Mohammad Iqbal dan Raditya Pandya Kusuma, Penanggulangan Orang Asing Yang Menjadi Korban Perdagangan Orang dan Penyeludupan Manusia di Bidang Keimigrasian

2020

(https://www.idntimes.com/news/indonesia/muha mmad-saifullah-3/warga-rohingya-yang-

terdampar-di-aceh-ternyata-korbanpenyelundupan/5).

Susiana, Sali, Dinar Wahyuni, Dina Martiany, Faridah Alawiyah, and A. Muchaddam Fahham. 2015. Perdagangan Orang: Pencegahan, Penanganan, Dan Pelindungan Korban. Jakarta: Pusat Pengkajian, Pengolahan Data dan Informasi (P3DI).

Yulistini, Anita, and Syarifah Arabiyah. 2017. "Fenomena Banyaknya Warga Negara Asing Yang Masuk Ke Wilayah Ri Tanpa Dilengkapi Dokumen Resmi (Studi Di Rumah Detensi Imigrasi Pontianak)." Journal of Chemical Information and Modeling 53(9):1689-99. 